\title{
COMMUNICATING WITH TARGET MARKET ENVIRONMENT
}

\author{
PhD Stanka Djurić \\ Tax Administration, Office Kragujevac \\ stanka.djuric@purs.gov.rs \\ PhD Svetlana Trajković, Professor \\ High School of Applied Studies, Vranje, Serbia \\ cecasvtr@yahoo.com
}

Professional Paper

doi:10.5937/jouproman4-11395

\begin{abstract}
The generally accepted definition that related to conceptual determination of market communication has not been performed. However, market communication can be defined as a set of activities and natural relationships that companies in various branches of authorities and business activities are established with other business organizations, and in order to establish a successful primary market communication, establishing a larger market share and the effective realization of the final goal, and certainly in market conditions that is profit. Activity which the company conducts are reduced to preparatory activities for the establishment of better relations with market operators, defining long-term strategies for successful business communication. The company has contact with their immediate environment, both internal and external. This, external environment emphasizing significantly because it consists of other economic organizations and entities, legal and regulatory bodies and consumers in order to take better starting position, preservation of the existing market share and also or extension thereof.
\end{abstract}

Keywords: business, communication, market environment

\section{INTRODUCTION}

The term "communication" comes from the Latin word communicare, meaning literally translates to disclose, publish, keep in touch, to correspond, to make common. Communication is a process of meaningful and understandable transmission of ideas thoughts and feelings among people. One of the understanding that the communication mechanism by which human relations exist and develop, and make it all the symbols of the spirit with the means of transmission. In fact, it is considered that communication is not bounded sizes such as spatial and time.
It can be said that communication is much more than just sending messages, so it includes such messages relating to: facial expression, posture, gestures, tone of voice, words, letter, message transfer agents, and all that leads achieving goals business, a supreme goal, as stated above, the achievement and profit maximization. "The public which addressed messages (audience) watching the environment, process information and make reasonable one hundred received."

Therefore, one can conclude with certainty that the communication:

- The device, which determines the existence of relationships between people,

- It is a continuous process through which relations between people becomes an act of exchange of information, ideas, emotions, experiences and everything that can lead to achieving the goals of the organization,

- The use of certain symbols is exchanged: the language as a communication tool, the elements of symbolic communication, etc.

Of course, the key role of the media and so much to represent the flow control instrument of communication, through the adaptation of content that is transmitted through the media, enable social control of communication).

\footnotetext{
${ }^{1}$ Kotler P, “Marketing Management”, (2000), Prentice-Hall International Editions, New Jersey, str.19
} 
As already stated, based on a review of literature that deals with the subject area it can be concluded that there are many definitions of communication, but none has been widely accepted character. Common to all is the understanding that communication is a process of information exchange between people.

Necessary skills and even the art of communication is certain to acquire learning. For successful communication it is necessary to have the skill to possess the skills and adaptability and teamwork. In doing so, it is important that the content inside the very way communication into line with the needs and requirements of the target audience, but it's ultimately the market, especially in the changed conditions, which are increasingly determining the term - the new economy. "Lately, you can often hear the most diverse signs that attempt to describe a new era in the development of the economy. They seem, however, that in this effort leading intellectuals who are not sure of the economics profession. In the constellation of diverse names that can be heard, or read more commonly in domestic and foreign professional economic literature, in this paper we deal with the issues and cases studies of some of the new economic doctrine, such as "green economy", "ecological economics", "creative economy", "knowledge economy". Of course, this list does not exhaust all the so-called new economy. This paper is an attempt to explain the origin and context of the emergence of certain "economy", their definition and the object of study and their importance for modern society."

\begin{abstract}
Business communication is any deliberate exchange of ideas and information exchange and opinions, and even giving certain instructions to target market groups, through symbols, signals or images, in order to achieve the main objective of the organization.
\end{abstract}

${ }^{2}$ Stošić-Mihajlović Ljiljana, Trajković Svetlana: 
Figure 1. Model of the process of business communication

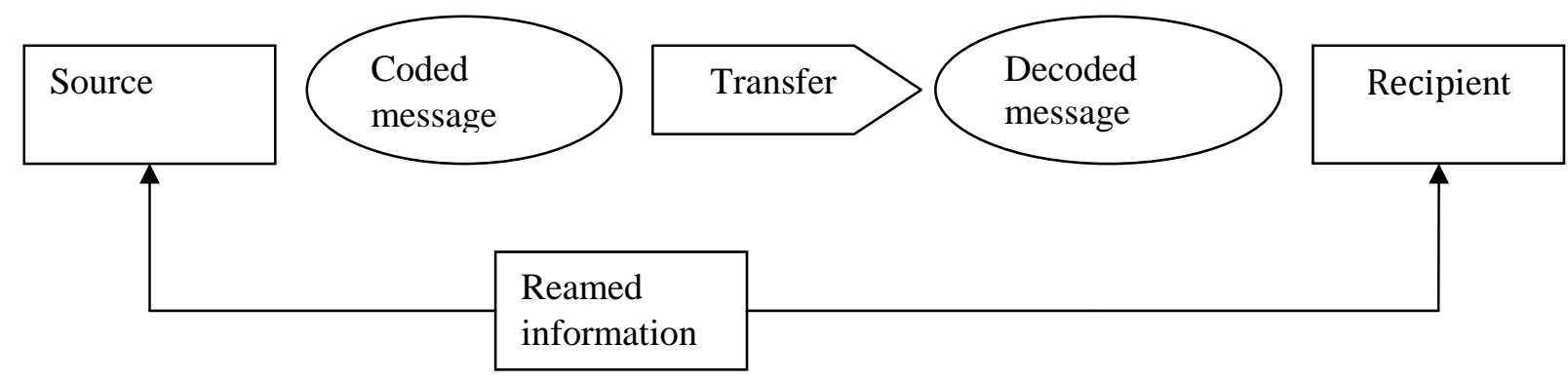

Source: P. Doyle, "Marketing Management and Strategy"

The picture shows a simple model of the communication process. As the figure suggests, the source (messenger) encodes the message by translating an idea that needs to be communicated in a symbol that consists of words and images, such as an advertisement. The message appears in the media, such as television or any other medium that is chosen based on certain criteria, and the main one is to be elected on the basis of their ability to reach the target audience and to appropriately.

Efficient and effective communication established contributes to the general understanding between the sender and recipient of the message. It is a notorious fact that all communication as the process will develop from the source of the message. After that is done adequate preparation message, and that is adapted to the specific activity of the recipient of the message, which means that it is oriented towards the target audience. It is important to note that the target audience can react in different ways. Expected way of reaction to the return message indicating whether the desires, needs and expectations are met or not. Specific and measurable level of customer satisfaction is the success criteria established relations of different participants in the process of business, primarily marketing communications with the environment.

\section{COMMUNICATIONS COMPANY AND ENVIRONMENT}

Past companies can be viewed with a high degree of reliability but the future can not. It has to be the projection of which in each case is uncertain. Uncertainty modern business enterprise is conditioned by the dynamic and complex environment that leads to new directions in business.

According to experts in the field of economics and management, the development of existing companies have a dominant influence economic, social, information and political (state) environment.

- As far as the economic environment, the maximum profit and minimum cost are the main aim and motive of business.

- Social impact involves the integration of economic and social value.

- Information environment has a major impact on business operations, in that regard, in order to make a profit, they must follow the modern trends in the development of science and technology achievements in information technology and modern management information systems. 
- Better knowledge of all categories of information technology allows better communication in the global market and favorable results in the international economy.

- The political environment is very important, especially in terms of making important strategic decisions.

- State regulations and political system in the country conditional synergistically functioning of environmental factors on the development of business systems and successful survival of the company in turbulent environment.

It is a notorious fact that in contemporary conditions, any change in the environment of such a character that relates to the change:

- Business conditions,

- The development of technology,

- Training methods, standards and

- Information systems.

Business management system must continually finds answers in modern, turbulent business environment. One possible form of the response in terms of developing their own strategies in the field:

- Specific business activities,

- Implemented business process automation,

- Integration

- The amount and types of information,
- Use of resources.

Changes in the business environment are reflected in the increase in the complexity and volatility of the business environment, increased competition and globalization of the economy, increasing social responsibility, a growing appreciation of the ethical requirements, modify the structure and the qualifications required of the workforce, but growing demands and expectations of customers, the accelerated technological innovation.

The environment in which the company operates can be divided into two major parts: the micro and macro environment. The main difference is in the area covered, or the importance of both invaluable to the company. Of critical importance is that the company follows the changes taking place in the micro and macro environment, adapt to them and implement them into your business process, because it is only taking into account the signals coming from the micro and macro environment the company can adapt and survive in the market. Incomprehension and indifference to global, and micro changes can only contribute to poor market positioning, loss of labor market and lack of competitiveness. The following table shows the macro and micro environment:

Table 1. Macro and micro environment ${ }^{3}$

\begin{tabular}{|l|l|}
\hline Macro Environment & Micro Environment \\
\hline Society, economy & Supply \\
\hline Consumers, competition & Economy \\
\hline Natural Environment & Production \\
\hline Technology & Credit \\
\hline Government & \\
\hline
\end{tabular}

Source: Milisavljevic, M., "The process of globalization of the world economy"

\footnotetext{
${ }^{3}$ Milisavljević, M., „Proces globalizacije svetske privrede“, (1998.), Marketing, broj 4, Beograd, Intermanet, str. 12 .
} 
Tempo changes in the business world is very fast. In particular, the competition in most of the activities taking place at an accelerating rate. Today's enterprises are faced with large risks on the one hand and the great opportunities on the other. It is necessary to balance between risks and opportunities. This is only possible if companies follow technological trends and requirements of the global economy.

A large number of companies did not function well in environments that are subject to constant and dynamic changes. Therefore, such enterprises have not realized profits but disappeared from the world market. Businesses need to change the philosophy of thinking about business.

Of critical importance is not only the possession of modern technology, but it is very important to know the market and its legality. If the weather anticipate all the needs and requirements of the market, we can make a profit.

The survival of the company and its progress in the modern conditions, depends exclusively on the possibilities of the company to adapt its product range, technology and product quality demands of modern market. This product is not only produced in order to sell more to fulfill the wishes and expectations of consumers. It is now very difficult to implement because the competition is increasing. The companies must be transformed into a leading enterprises that will generate differential advantage in the global marketplace.

Knowing the competition is of great importance for the company. It is therefore necessary to monitor what competitors are doing, and always be one step ahead of them. Company number one in the business world it is a company that is on time accepted the modern concepts of operations and its business activity adapted to current developments in the region.

To maintain awareness of the necessity for change requires information processing systems of high business 34 performance - modern information technology. This information shall contain data on the market, consumers, employees, shareholders, suppliers, competitors and financial results. Systems that provide this information must be developed to provide a true and real information. Thus was formed the system allows communication and helps companies to more easily and successfully transformed cope with the dynamic changes in the environment.

The current company their activities in conditions of complex environments, so it is necessary to apply a strategy adequate to these conditions. Modern business strategy includes achieving good results that will be achieved by the latest developments in the field of innovation, TQM, reengineering and information technology.

The speed with which decisions need to be constantly increasing, and the shortening of product life cycle requires skillful management, how to get out as much profit as soon as possible. These are just some of the reasons pointing to the importance of good information and analysis of the business environment, and even more - a good marketing information system for the modern business enterprises and the success of its marketing.

Marketing information system is located between the environments in which are contained the chances and risks, and managers, who on the basis of data on the status and impact factors of external environment and internal information about the possibilities, take appropriate marketing activities. It is thanks to a well-developed MIS, which is a focal point at which they intersect information from different sources, the company is able to anticipated needs answers faster and better than the competition, and on that basis a profit. 
Furthermore, Business Intelligence enables proactive way of running the business, which means that it can predict the future, create several scenarios and be prepared for any situation. Today, the water company on the basis of knowledge about competitors, customers, suppliers, processes. BI is the production of knowledge that is the basis for making business decisions, and reduces the risk of the impact of environmental factors on the results of operations of the company.

The fact is that the main driver of change in the company human resources. Modern company more time to the development of leaders - people who can create and transfer to other vision and strategy. Without enough productive leaders create a vision, training people to accept the need to change, no transformation of enterprises. Developing leadership is a long process that carries with it some risk. This risk should be taken over to investigative findings were favorable.

Satisfaction of basic economic principles of the company can achieve positive business results. However, it is not enough for the more distant future, the company in a turbulent environment. World globalization and dynamic environment, many companies stated that they have to learn to adapt to an unstable world market. The competence of the company will be a trademark of the business world. Incompetent companies quickly perish because they did not succeed in time to complete the transformation and adapt their organizational structure and strategy developments in the market.

It is important to consider the importance of mutual links and influence of companies, state structures and the overall environment of the relevant business activities.

These connections and influences have a significant impact on the management activities of the company and its development strategy. Also, it is important to build and ability to solve specific problems in business resulting from the impact of the public, social, political and institutional environment to conduct business strategy of the company.

\section{MARKETING APPROACH IN BUSINESS COMMUNICATION}

\author{
"If I had the last marketing \\ dollar, I'd spend it on PR" - Bill Gates \\ "PR is an art that people offer \\ reasons to convince yourself" - Michael \\ Levin ("Guerrilla PR Wired")
}

"Modern marketing approach is based on the growing importance of integrated marketing communications and social - responsible marketing concept. Modern marketing mix does not take into account only meet consumer needs but also the realization of long-term, integrated communications with him. ${ }^{5}$

"The concept of developing a brand identity refers to the increasingly dominant impact of different marketing communication strategies in order to create, develop brand and establish stronger emotional connection with the consumer. The added value that the brand returns linked to, in addition to functional, for its symbolic and emotional way. The concept of integrated marketing communications enables companies to a variety of communication strategies, target communicate a consistent message to the public that the brand carries such persuasive, consistent and clear. "6

"Sports is an area of business where competition is fierce and where a number of leading brands, such as Nike, Adidas, Reebok and Puma fight to win the hearts, mind and, what is more, and most importantly - consumers' wallets.

\footnotetext{
${ }^{4}$ http://www.savremenisport.com

5 Vračar D.," Strategije tržišnog komuniciranja", (2005), Ekonomski fakultet u Beogradu , str. 25

${ }^{6}$ Duncan T., IMC, Using Advertising and Promotion to Build Brands, (2000) McGraw-Hill, New York, str.19.
} 
These brands are spending millions per year promoting their products around the world. After the famous collaboration with the American company Nike basketball star Michael Jordan, the leading company for the production of sporting goods compete in the signing of contracts with the hottest sports stars to promote their products.

For example, the engagement of players is critical to improving sales in the US market shoes, which is the largest in the world. Therefore, the company Nike was extremely pleased when he signed a contract worth 90 million dollars with the Le Bron James, since it seems that only Adidas and Reebok have a chance to engage. Van United States Adidas was more successful because they are David Became and Jonny Wilkinson, the most popular footballer and rugby player, agreed to promote his products. "Given the versatility of techniques that marketers have at their disposal, the main marketing decision involves the choice of the promotional mix that is required to communicate with the target audience. Each of promotional activities has its advantages and disadvantages."7

"Marketers carefully compare all the factors with promotional goals to decide what level of resources necessary to assign each asset. For example, in 2002, the company Unilever is one of the largest companies for the production of consumer goods, has spent 7.3 billion dollars on marketing, while slightly more than half that amount, \$ 4 billion was spent on propaganda." ${ }^{8}$

\footnotetext{
${ }^{7}$ http://www.global.adidas.com/

${ }^{8}$ Jober D., Fahy J., “Osnovi marketinga”, (2006),

Data status, London, str. 224.

\subsection{FACTORS THAT HAVE IMPACT ON THE CHOICE OF PROMOTIONAL MIX}

Factors that tend to have a major impact on the selection of promotional mix are:

1. Availability of resources and the cost of promotional tools - implement a national publicity campaign can cost several million pounds. If a company does not have so many resources, she may need to use less expensive means such as sales promotion and publicity.

2. Market size and concentration - if the market is small and concentrated, then personal selling might be feasible, but for the mass markets that are geographically dispersed, sales to end customers would not be cost-effective. In such circumstances, propaganda or direct marketing may be the right choice.

3. The needs of customers for information - if it is necessary to give an explanation of complicated technical nature, personal selling can be the right solution. If the appropriate brand image all you need, then it is propaganda acceptable solution.

4. Product Features - due to the above arguments, the companies that produce industrial goods, mainly spend more on personal selling than on propaganda, while the companies that produce commodities reverse is the case.

5. Push versus pull strategy - push distribution strategy involves an attempt to sell the product to intermediaries in the distribution channel (for example: retailers) and relies on personal selling and sales promotion for business customers. Pull strategy for consumers bypassing intermediaries to establish direct communication with consumers. The resulting demand for consumer products according intermediaries to place the product in their offer. Funds that are commonly used for this are propaganda and sales promotion for consumers. 
As the spectrum of promotional techniques expands, the need for coordination of messages and their execution. This problem is often aggravated by the fact that, for example, manages the propaganda department of propaganda, while the strategy of personal selling is determined by the department for personal sales, resulting in a lack of coordination.

This problem has led to an increasing number of companies introduced integrated marketing communications. Integrated Marketing Communications represent system by which companies coordinate their marketing communications to communicate a clear, consistent, credible and specific message about the organization and its products. For example, it means that the appearance of the site should be in line with the figures presented in the propaganda and messages that are transmitted in a direct marketing campaign should be relevant to the messages that devises department in public relations.

Application of the concept of integrated marketing communication can lead to a more consistent and clear positioning of companies and their brands in the minds of consumers. One of the companies which has brought the benefits of this approach is a company American Express, which has realized that message, image and style of presentation of its funds for propaganda and direct marketing are not consistent. The team of the company has applied the concept of integrated marketing communications to achieve consistency, which is necessary for the delivery of a clear position in the target audience.

For many small and medium-sized companies planning marketing communications are reduced to cost estimates by the company can not afford, the deployment of these costs to specific media, and when the time comes, the assessment of whether or not sales improved. Of course, to avoid wastage of valuable organizational resources, you need to carefully plan and evaluate marketing communications.
The very process of planning and evaluation of marketing communication begins by examining the marketing strategy of the company, its strategy and positioning and its planned target audience, the existing market but also with regard to the potential supply and potential markets.

It begs the question: What company could achieve on the market, what role that may have a marketing communication, whether and how marketing communication can improve business in the short and long term? For example, when the company is trying to reposition its brand propaganda then it will have an important role in this, for it is quite certain that it must be linked to other elements of the marketing mix, primarily with the product and attributes. "We need to set goals for IMS $^{9}$ campaign and they should be such that they can be accurately measured. For example, the goal may be to increase sales by a certain amount or a certain percentage increase awareness of the brand among young people. Only after this phase nearing completion, the company needs to start thinking about what to say (decisions about the message), and where and how to say it (the decision of the promotional mix). These are complex decisions, which must be considered in detail. It is necessary to determine the budget for the company, which is usually the responsibility of the board of the company. Then, after conducting a trickle, it is extremely important to assess its effectiveness." 10

The reason for the constant check effectiveness and efficiency of marketing campaigns is the fact that the time and money a very limited resource that, in addition, costs a lot. Therefore, it is necessary to continuously measure the relationship between costs, benefits and time of return on investment, especially those that invested in marketing campaigns of the company.

\footnotetext{
${ }^{9}$ IMS - - Integrated Management Strategy

${ }^{10}$ Jober D., Fahy J., “Osnovi marketinga”, (2006),

Data status, London, str. 224.
} 


\section{CONCLUSION}

From the above, we can clearly understand the importance of marketing communications, as well as the nature of the relationship to the environment. Neither company, as an individual for himself, he can not succeed alone. In fact, every company has to coordinate its business activities with its environment. For this reason, must adapt to the market and governed by the principle only the best can survive. This principle is equally applicable in both the living world, and organizational systems, such as companies.

In this paper, we have seen the importance of communicating the company with the environment, how can all interact with the environment, what are the benefits weighed against the costs and time as a limited resource, as well as all kind of traps can be company encounter this exchange of information.

Defining a long-term strategy is one of the starting factor of communication enterprises with the environment. The very process of communication depends a lot on defining these strategies, these and ways of implementation. Even if the defined longterm strategy, but there is no timely operationalization for shorter periods and tighter organizational units, communication process will be unsuccessful and will bring no benefit company.

\section{REFERENCES}

1. Vračar D.," Strategije tržišnog komuniciranja”, (2005), Ekonomski fakultet u Beogradu, str. 25

2. Duncan T., IMC, Using Advertising and Promotion to Build Brands, (2000) McGraw-Hill, New York, str.19

3. Jober D., Fahy J., "Osnovi marketinga", (2006), Data status, London, str. 224.

4. Kotler P, "Marketing Management", (2000), Prentice-Hall International Editions, New Jersey, str.19.
5. Milisavljević, M., „Proces globalizacije svetske privrede“, (1998.), Marketing, broj 4, Beograd, Intermanet, str. 12.

6. Stošić-Mihajlović Lj., Trajković, S., Modern economy: Features and developments, Journal of Process Management. New Technologies 2016, vol. 4 , br. 2, str. $17-25$

7. http://www.global.adidas.com/ 